\title{
JORDUNDERSÖKNINGAR I TYSKLAND OCH DERAS BETYDELSE FÖR DET PRAKTISKA JORDBRUKET
}

\author{
Föredrag av Dr. H. Riehm, \\ Augustenberg, Baden-Württemberg, Tyskland, i Helsingfors \\ den 14. 9. 1952.
}

Vid det årsmöte med „Verband Deutscher Landwirtschaftlicher Untersuchungsund Forschungsanstalten» i Bad Kreuznach, varifrån jag just har kommit, betonade dess president Prof. Dr. Schmitt, Darmstadt, att vi i dag bestämt veta att $50 \%$ av de skördestegringar som uppnåtts under de sista 100 åren, bero på jordnäringskapitalets komplettering med handelsgödsel. I dag används ju också mycket stora mängder sådana gödselmedel i Europa. De 19 europeiska länder, som äro anslutna till OECE, använde år 1950/51 9 milj. ton kvävegödselmedel, 14 milj. ton fosfatgödselmedel och 5 milj. ton kaligödselmedel, alltså sammanlagt 28 milj. ton. För år 1952/53 förtutses en förbrukning av 35 milj. ton. Gödselmedelsförbrukningen är mycket olika i de olika länderna, så som framgår av tab. 1 (c.l. 7).

Tab. 1. Förbrukning av handelsgödselmedel i några europeiska länder

\begin{tabular}{|c|c|c|c|c|c|}
\hline & \multicolumn{5}{|c|}{$\begin{array}{c}\text { Gödselmedelförbrukning i kg/ha } \\
\text { jordbruksareal }\end{array}$} \\
\hline & \multicolumn{4}{|c|}{$1950-51$} & \multirow{2}{*}{$\begin{array}{c}1952 / 53 \\
\mathrm{~N}+\mathrm{P}+\mathrm{K}\end{array}$} \\
\hline & $\mathrm{N}$ & $\mathrm{P}$ & K & $\mathrm{N}+\mathrm{P}+\mathrm{K}$ & \\
\hline 1. Portugal & 6 & 11 & 1 & 18 & 19 \\
\hline 2. Grekland & 8 & 10 & 3 & 21 & 29 \\
\hline 3. Italien & 8 & 14 & 1 & 23 & 29 \\
\hline 4. Österrike & 7 & 14 & 8 & 29 & 40 \\
\hline 5. Frankrike & 10 & 16 & 14 & 40 & 65 \\
\hline 6. Schweiz & 7 & 26 & 10 & 43 & 45 \\
\hline 7. Danmark $^{1}$ ) & 22 & 26 & 29 & 77 & 86 \\
\hline 8. Tyskland & 26 & 29 & 47 & 102 & 131 \\
\hline 9. Belgien & 46 & 52 & 67 & 165 & 194 \\
\hline 10. Holland & 68 & 54 & 66 & 188 & 180 \\
\hline
\end{tabular}

1 Därtill en stor mängd stallgödsel. 
Tab. 2. Jämförelse mellan skörden i fullgödslade fältförsöks parceller och riksmedeltalet

\begin{tabular}{lcccc}
\hline Skörd & $\begin{array}{c}\text { Antal } \\
\text { försök }\end{array}$ & $\begin{array}{c}\text { Fullgödslad } \\
\text { försöks- } \\
\text { parcell } \\
\mathrm{kg} / \mathrm{ha}\end{array}$ & $\begin{array}{c}\text { Riks- } \\
\text { medel- } \\
\text { tal } \\
\mathrm{kg} / \mathrm{ha}\end{array}$ & $\begin{array}{c}\text { Procen- } \\
\text { tuell } \\
\text { skörde- } \\
\text { ökning }\end{array}$ \\
\hline Korn & 10800 & 2830 & 2080 & 36 \\
Potatis & 7400 & 26300 & 17300 & 52 \\
Sockerbetor & 1400 & 40000 & 31600 & 27 \\
Foderbetor & 3300 & 80000 & 34500 & 230 \\
Ängshö & 4100 & 7830 & 4660 & 68 \\
\hline
\end{tabular}

Som synes, är förbrukningen tio gånger större i de länder vilka ha den största förbrukningen, jämfört med dem som ha den minsta. Finland använder ungefär $40 \mathrm{~kg}$ (kväve + fosforsyra + kali), alltså ungefär lika mycket som Frankrike. Även om till exempel Holland redan nästan har nått högsta tänkbara gödselmedelförbrukning, så har denna icke på långt när nåtts i de flesta andra länder, icke heller i Tyskland.

Av tab. 2 framgår vilka stora reserver som ännu finnas i mitt land, och vilka kunna utnyttjas genom starkare gödsling. I tabellen har genomsnittskördarna med fullgödsling i fältförsök jämförts med riksmedeltalen för åren 1935/39 (5). Dessa fullgödslade försöksrutor fick i genomsnitt en gödsling av $40 \mathrm{~kg}$ kväve, $60 \mathrm{~kg}$ fosforsyra och $80 \mathrm{~kg}$ kali pr ha, tillsammans alltså $180 \mathrm{~kg}$ näringsämnen (ungefär lika mycket som man i genomsnitt använder i Holland) medan riksmedeltalet för givorna under dessa år endast var $23 \mathrm{~kg}$ kväve, $22 \mathrm{~kg}$ fosforsyra och $27 \mathrm{~kg}$ kali. De fullgödslade försöksrutornas högre skördar i jämförelse med riksmedeltalet förorsakas till största delen av dessa större gödselgivor.

Emellertid måste vi känna jordens näringstillstånd innan vi rätt kunna utnyttja de större gödselgivornas möjligheter. Kännedom därom kan vi få endast genom jordanalyser. Med jordanalys förstå vi i Västtyskland i dag en näringsämneskontroll av jorden, vilken regelbundet upprepas vart tredje till femte år. Denna kontroll är i dag praktiskt genomförbar endast för näringsämnena fosforsyra, kali och kalk men inte för kväve. De för växterna viktiga kväveföreningarna, särskilt nitrat, äro underkastade mycket större variationer i jorden om de undersöks vid olika tidpunkter. I motsats härtill är jordens innehåll av näringsämnena fosforsyra, kali och kalk praktiskt taget konstant under årets lopp och kan därför läggas till grund för bedömning av lämplig gödsling.

Av mest grundläggande betydelse är kalkundersökningen, då ett tillfredsställande kalktillstånd hos jorden är en förutsättning, för att all annan gödsling skall komma till sin rätt. Som vi senare skola finna, är våra jordars fosforsyra- och kalitillstånd i många fall dåligt, och bestämningar av dessa är därför också absolut nödvändiga.

Vid jordundersökningar är det tre helt olika problem, som vi måste ta ställning till: provtagningen, den kemiska analysen och tolkningen. 


\section{Provtagningen (c.1. 8, 9)}

Då jordens innehåll av näringsämnen kan vara mycket olika på ställen, som ligger bara ett par meter från varandra, är det nödvändigt att arbeta med blandprov. Vi ta därför på de arealenheter som skola undersökas och som böra väljas så små som möjligt $-1 / 4$ till 1 ha, i varje fall icke större än 2 ha - med jordborr 15 till 20

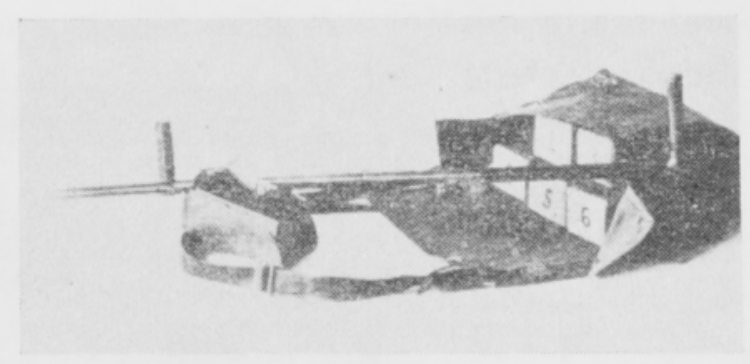

Bild 1. Jordborr med avstrykningsbägare och kartonger för prover. prov, likformigt fördelade över provytan, och slå ihop dessa till ett blandprov. På öppen åker ta vi i regel proven till $20 \mathrm{~cm}$ djup, på betesmark däremot endast till $10 \mathrm{~cm}$ djup, på grund av att rotskiktet där är så mycket tunnare. I många fall är det lämpligt att också ta alvprov, som dock måste undersökas för sig.

På bild 1 visas en provborr av den typ vi använda. Den har fotsteg — för åkèr vid $20 \mathrm{~cm}$, för äng vid $10 \mathrm{~cm}$ djup — som underlättar nedtryckningen och säkerställer konstant provtagningsdjup. Jorden skrapas med avstrykningsjärnet direkt ned i provtagningskartongen. Kartongen för åkerjord rymmer omkring 15, den för betesmark omkring 30 provstick. Egna undersökningar över provtagningens reproducerbarhet ha visat att 15 delprov räcker för att ge ett tillförlitligt blandprov när det gäller åkerjord. På beten och ängsmark är näringsämnenas fördelning mer oregelbunden, varför ett större antal delprov är önskvärt.

Den gynnsammaste provtagningstiden är efter skörden men före eventuell gödsling, helst efter den sista grödan i växtföljden. Om det däremot gäller att

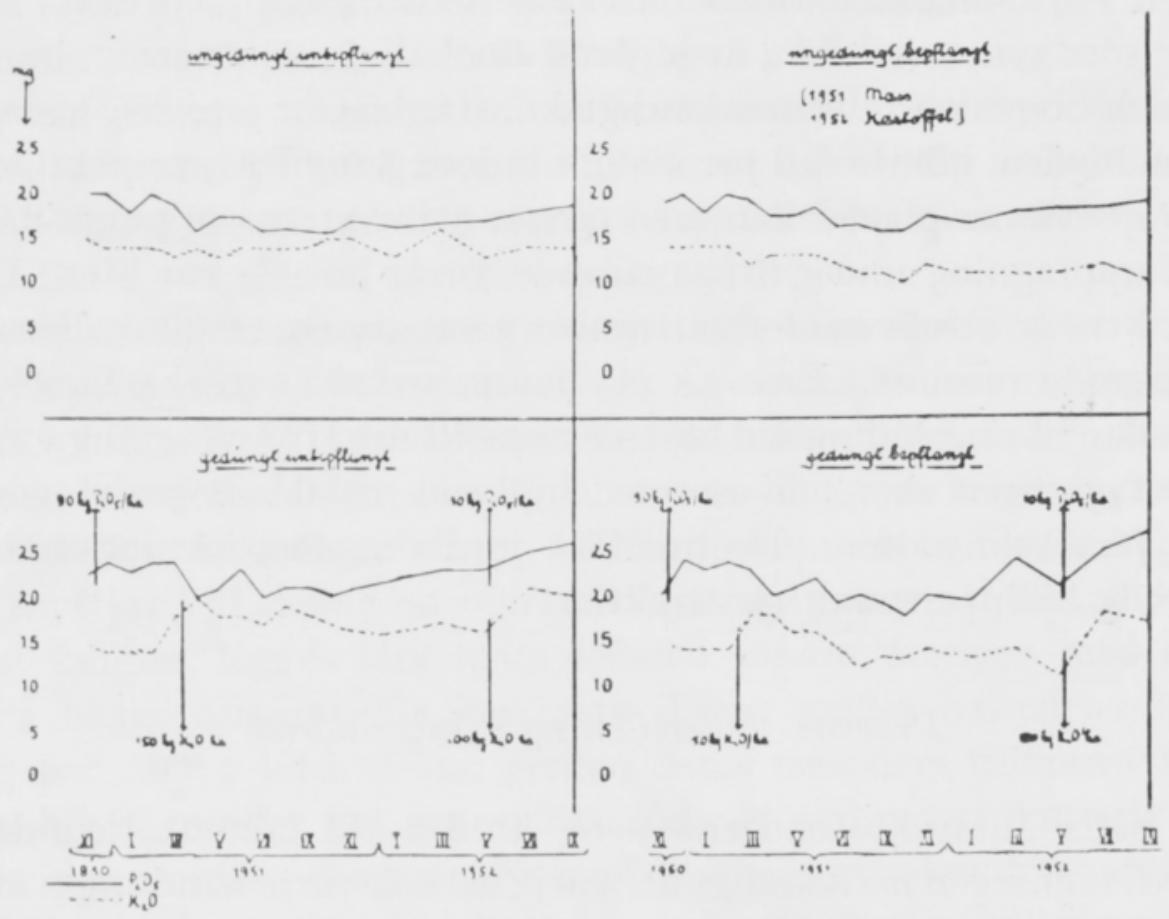

Bild 2. Variationer med tiden i jordens innehåll av växtnäringsämnen.

Ovan t. v.: ogödslad, obevuxen

Nedan t. v.: gödslad, obevuxen
Ovan t. h.: ogödslad, odlad

Nedan t.h.: gödslad, odlad 


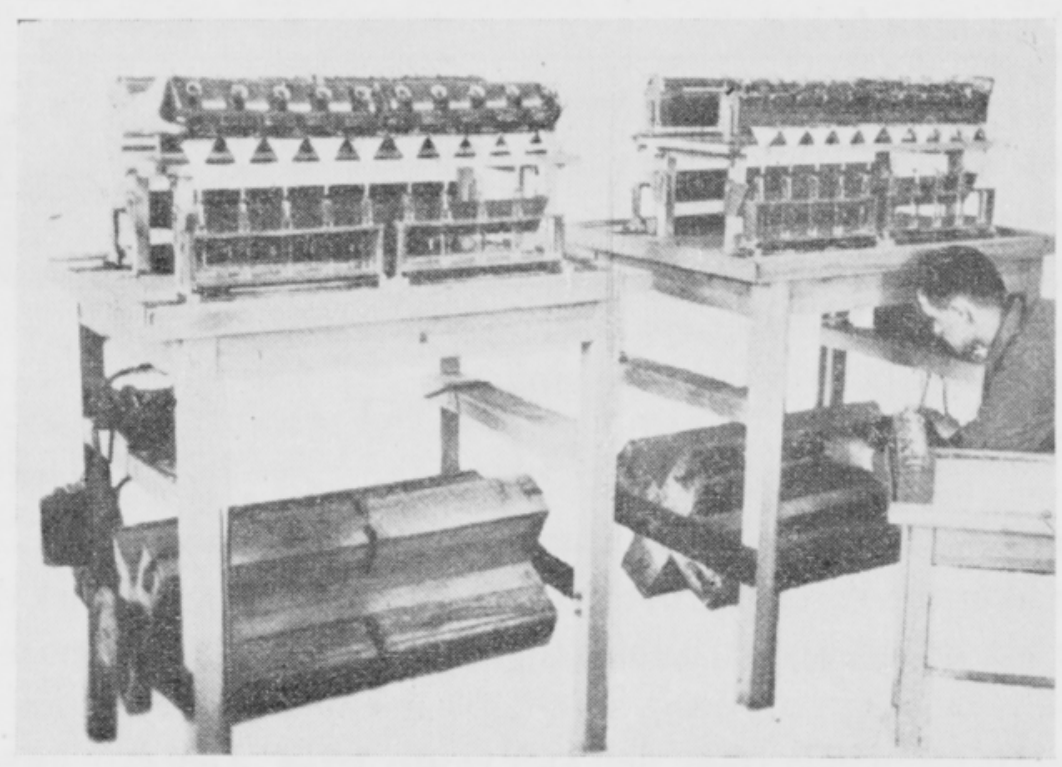

Bild 3. Skak- och filtrerbord enligt Riehm-Aptila.

söka få en samlad översikt av ett område eller en gård, så kan proven tagas vid vilken annan tid som helst. Den enda tidpunkt, när provtagning icke får företagas, är kort efter en gödsling, framför allt en sådan med stallgödsel.

BROUWER (1) har gjort gällande att jordens innehåll av näringsämnen kan variera synnerligen starkt med provtagningstiden, och har av denna orsak uttalat tvivel om jordundersökningars värde överhuvudtaget. I ett gemensamtarbete i min fackgrupp för jordanalyser i "Verband Deutscher Landwirtschaftlicher Untersuchungs- und Forschungsanstalten" ha vi emellertid funnit, att dessa farhågor icke äro befogade; som synes av bild 2 är jordens innehåll av växtnäringsämnen, om den är ogödslad och obevuxen, utomordentligt konstant. Om jorden gödslats, kan den givna gödselmängden, i detta fall per 100 gram jord $3 \mathrm{mg} \mathrm{P}_{2} \mathrm{O}_{5}$ respektive $7 \mathrm{mg} \mathrm{K}_{2} \mathrm{O}$, återfinnas. På bevuxna platser kan man påvisa att växterna upptagit näringämnen, ehuru denna upptagning under ifrågavarande torrår hos oss var liten. Dessa försök ha nu pågått $\mathrm{i}$ tre år och även $\mathrm{i}$ fortsättningen visat samma resultat. Försök på andra håll gåvo liknande resultat. FRANCK (4) har ju också i svenska försök funnit, att skillnaden mellan näringshalten vid höst - respektive vårprovtagning var oväsentlig.

Jordprovtagningen sker hos oss med hjälp av utbildade provtagare, som äro underställda försöksanstalten. De medföra jordborr, förpackningsmaterial o.s.v., men få behövlig hjälppersonal från trakten.

\section{Provens undersökning $i$ laboratoriet}

För att hålla analyskostnaderna nere, är det vid laboratorieundersökningen liksom vid provtagningen nödvändigt att varje fas och varje handgrepp är noggrannt planerade. Vi ha t.ex. nu maskiner för jordsållning, specialvågar, specialskakmaskiner, specialfiltrerbord etc. I allmänhet äro jordundersökningslaboratorierna inrättade enligt det löpande bandets princip (bild 3). 
Som skakflaskor användas »konhalsflaskor», som kan skakas i lådor under bordet. Efter fullbordad extraktion ställas flaskorna upp på bordet. Med ett handgrepp kunna 10 flaskor samtidigt filtreras. Filtratet rinner direkt ned i kolorimeterrören. Kapillarhävertar hindra att rören fyllas för högt och flöda över.

De på föreskrivet sätt tagna jordproven skickas in till laboratoriet, där de lufttorkas, finfördelas och sållas. I de sållade proven göras på finjorden därefter följande kemiska bestämningar:

a) Kalkbehovsbestämning enligt SchachtschabeL (14).

Denna metod antogs vid VDLUFA:s årsmöte 1950 som förbundsmetod. Den är en förenkling av KAPPENS metod för bestämning av hydrolytisk aciditet. Vid den senare bestämningen skakas jorden som bekant med kalciumacetatlösning; allt efter jordens syrahalt bildas därvid större eller mindre mängd ättiksyra, som bestäms genom titrering av tiltratet. Schachtschabels modifikation innebär endast, att man icke filtrerar eller titrerar, utan beräknar den frigjorda ättiksyran ur jordsuspensionens pH-depression. Dessutom måste också en pH-bestämning i 1-n KCl genomföras. Hela kalkbehovsbestämningen inskränker sig därför till två pH-bestämningar. Ur tabeller kan man ur de båda pH-värdena direkt avläsa de kalkmängder, som äro nödvändiga för att kalka upp de olika jordarna till önskat pH-värde.

b) Bestämning av jordens fosforsyre- och kalibehov enligt EGNÉR-RIEHMS $(2,3,10)$ laktatmetod.

Det väsentliga i denna metod är valet av lämpligaste extraktionslösning, en med kalk halvneutraliserad svag mjölksyrelösning. Denna lösning har ett pH av 3.7 , och är väl buffrad mot ändringar i såväl väte- som kalciumionkoncentration, två faktorer, som ha stort inflytande på fosforsyrans löslighet. Vid jordundersökningen betyder detta, att olika jordar extraheras under lika betingelser.

Det för växterna upptagbara kalit föreligger i jorden i upptagbar form. För dess bestämning har EGNÉR föreslagit en buffrad monoklorättiksyralösning. Numera bestämma vi enligt mitt förslag även kalibehovet med hjälp av laktatextraktet, så att det för bestämning av såväl fosforsyre- som kalibehovet räcker med en enda extraktion. Detta betyder en stor förenkling.

Den kemiska bestämningen av fosforsyra och kali i jordfiltratet är utomordentligt enkel och lättgjord. För fosfatanalysen användes en kolorimetrisk metod: till filtratet sättes två reagens, som tillsammans ge blåfärgning med fosfat. Blåfärgningen mätes med selenfotoelement i en apparat, som liknar en belysningsmätare av den typ, som användes vid fotografering. Kalibestämningen är lika enkel.

Man utnyttjar vid denna en ofärgad lågas egenskap att färgas violett genom införande av kalium; lågans färg mäts sedan i sin tur återigen med ett selenfotoelement. På bägge apparaterna kan man direkt avläsa halten av ifrågavarande ämne i mg per $100 \mathrm{~g}$ jord. Först genom dessa metoders tillkomst har det överhuvudtaget blivit möjligt att genomföra sådana jordundersökningar i stor skala. I dag kunna vi genomföra dessa analyser på lika många sekunder som förut timmar.

I det följande skola vi gå in något på analysresultatens tolkning, ty först efter en sådan kan undersökningsanstaltens arbete göras nyttig för den praktiske jordbrukaren. 


\section{Analysresultatens tolkning}

Genom Schachtschabels kalkbehovsbestämning erhăller man, som redan omtalats, direkt det antal deciton kalk (CaO), som behövs för att ge jorden önskat $\mathrm{pH}$-värde. Som bekant skall jordarna alltefter jordart kalkas upp till olika $\mathrm{pH}$ värden. Leror och lättleror kunna t.ex. kalkas upp till $\mathrm{pH} 7.0$, sandiga lerjordar t.ex. lössjordar till pH 6.5, och leriga sandjordar, t.ex. vad vi i Tyskland kalla Buntsandsteinböden till pH 6.0. De rena sandjordarnas uppkalkning rättar sig efter deras humushalt, lerhalt och kulturtillstånd. Hedsandjordar kalkas i allmänhet upp till pH 5.5, ett pH-värde, som är tillräckligt högt för råg, havre, potatis och lupiner. Svämsandjordar, tertiära sandjordar och keupersandjordar kunna kalkas upp till pH 6.0, om lerhalten är relativt hög. Även vid regelbunden riklig stallgödsling liksom för anspråksfulla kulturväxter så som grönsaker, korn, vete, sockerbetor och luzern, kan sandjordarnas uppkalkning lämpligen drivas ända till pH 6.0—6.5.

Ur Schachtschabels tabeller kan kalkbehovet till önskat pH-värde avläsas. På styva jordar är även vid neutral reaktion en kalkning med bränd kalk befogad, varigenom jordens fysikaliska tillstånd förbättras.

Något mera invecklad är fosforsyra- och kalilaktattalens tolkning. Med deras hjälp bestäms "jordklass» under hänsynstagande till $\mathrm{pH}$-värde och jordart. Vid höga tal hänföras jordarna till klass I och erhålla normal gödsling, ungefär motsvarande vad grödan beräknas ta upp, så att jordens goda näringstillstånd bibehålles efter den nya skörden. Jordar med medelhöga tal hänföras till klass II och erhålla förstärkt gödsling i avsikt att om möjligt föra upp dem till klass I, medan jordar med de i klass III förekommande låga talen måste erhålla mycket stark gödsling.

Det är svårt att giva för större områden allmängiltiga gödslingsråd. Gödslingen måste rätta sig efter jord, växt, klimat och framförallt driftsformen på ifrågavarande jordbruk. Följande tabell kan därför endast ange anhaltspunkter för lämplig gödsling. I tabellen 3 föreslagna gödselmängder förutsätter vanliga stallgödselgivor.

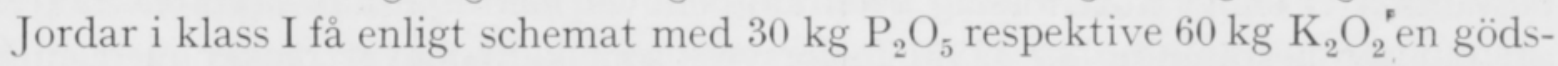
ling, med vilken man i allmänhet inte kan uppnå några nämnvärda skördestegringar, men som är obetingat nödvändig som ersättningsgödsling, då: utarmas. Jordar i klasserna II och III få med 60 och $90 \mathrm{~kg} \mathrm{P}_{2} \mathrm{O}_{5}$, respektive 120 och

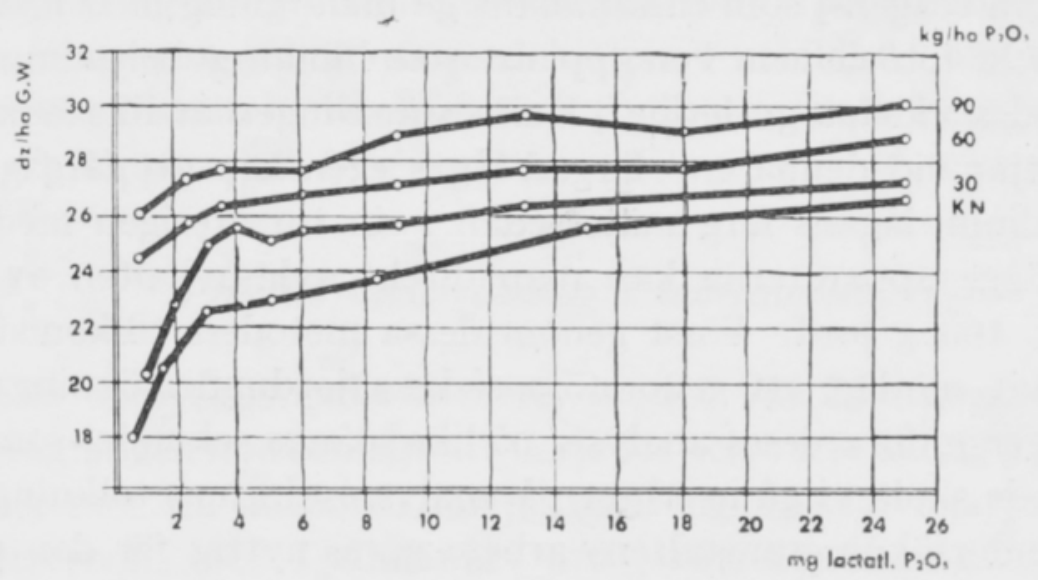

Bild 4, Skördestegningar genom fosfatgödsling. 
Tabell 3. Enkelt gödslingsschema

\begin{tabular}{|c|c|c|c|c|c|}
\hline $\begin{array}{l}\text { Behovs- } \\
\text { klass }\end{array}$ & $\begin{array}{l}\text { Näringsämnes- } \\
\text { försörjning }\end{array}$ & $\begin{array}{l}\text { Karte- } \\
\text { rings- } \\
\text { färg }\end{array}$ & $\begin{array}{c}16-18 \% \\
\text { P-gödsel } \\
\text { kg/ha }\end{array}$ & $\begin{array}{c}40 \% \\
\text { K-gödsel } \\
\text { kg/ha }\end{array}$ & $\begin{array}{l}\text { Gödslin- } \\
\text { gens art }\end{array}$ \\
\hline I & för tillfället försörjd & blå & 200 & 150 & ersättning \\
\hline II & måttligt försörjd & grön & 400 & 300 & överskott \\
\hline III & dâligt försörjd & röd & 600 & 400 & anrikning \\
\hline
\end{tabular}

$160 \mathrm{~kg} \mathrm{~K}_{2} \mathrm{O}$ en överskotts- respektive anrikningsgödsling, som med stor säkerhet leder till stora skördestegringar.

Bild 4 visar vilka följder dessa gödslingsråd har för jordens prestationsförmåga. Tabellen sammanfattar resultat från 1300 gödslingsförsök och har sammanställts av GERICKE (6).

Kurvan »utan fosfatgödsling», alltså NK-kurvan, visar att skörden stiger med stigande fosfathalt i jorden. De tre kurvorna, motsvarande givor om 30,60 och $90 \mathrm{~kg}$ $\mathrm{P}_{2} \mathrm{O}_{5}$ per ha, visar att den av fosfatgödslingen föranledda skördestegringen är desto större, ju lägre jordens fosfathalt är. Genom motsvarande fosfatgödsling kunna vi utjämna skillnaderna mellan olika jordars produktionsförmåga.

På sista tiden ha vi börjat att samtidigt med resultaten överlämna ett litet häfte med gödslingsråd. Av detta framgår att vi allt efter deras bördighet har delat in jordarna i tre bördighetsklasser. Inom varje sådan klass rekommenderas sedan gödsling allt efter näringsinnehåll och avsedd gröda.
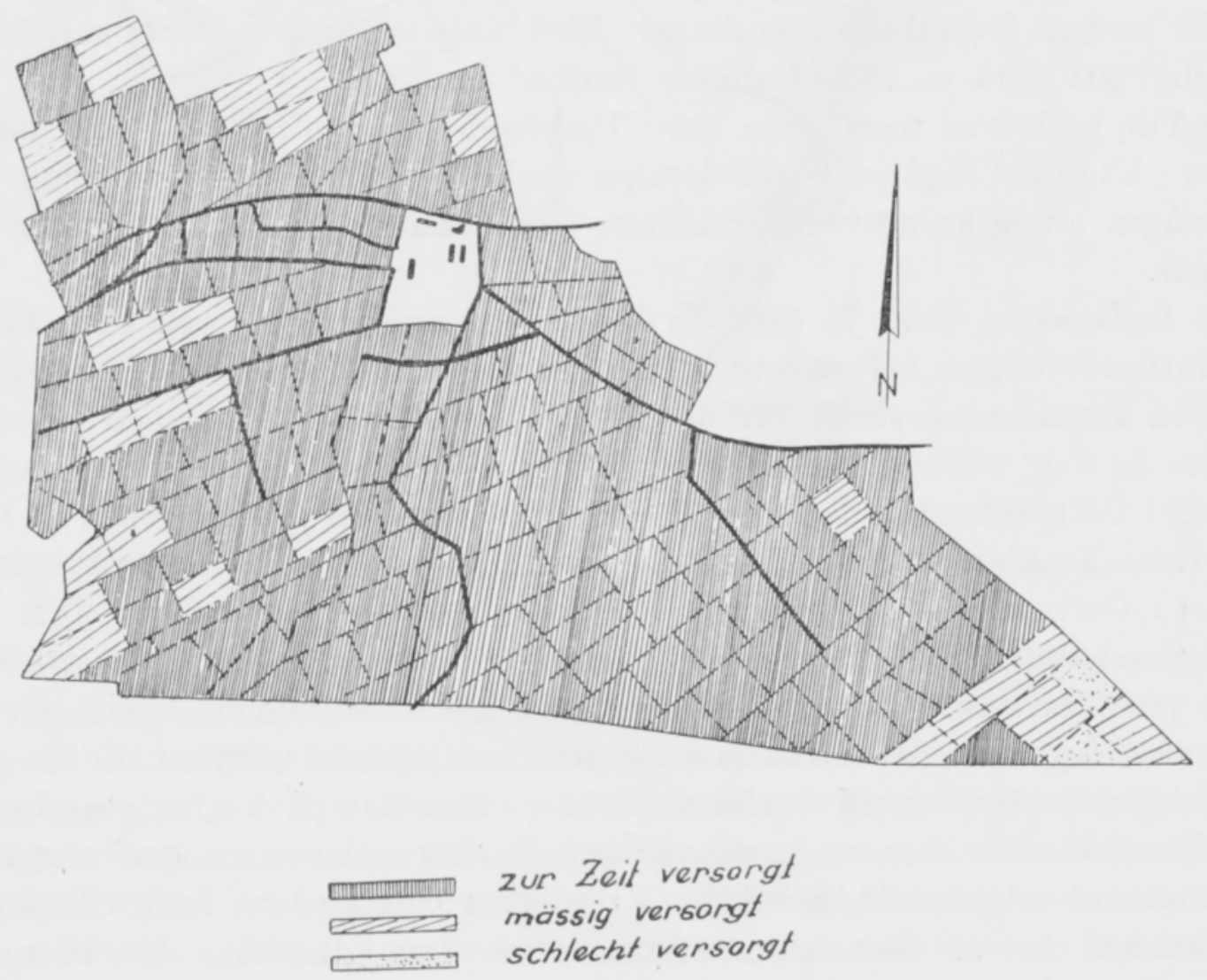

Bild 5. Fosforsyreförsörjning på ett "Hofgut». 
Det har visat sig vara särdeles lämpligt att åskådliggöra analysresultaten i form av kartor: försörjningen med olika näringsämnen återges med färger enligt tabell 3. Jordbrukaren får på så sätt en god överblick över läget på sin gård.

Kartan (bild 5) återger fosforsyreförsörjningen på ett "Hofgut», alltså ett jordbruk, som i motsats till gårdarna i en typisk sydtysk by har ägorna samlade i ett block. Jorden är jämförelsevis väl försörjd med fosforsyra; endast på ett fåtal utägor, som nyligen tillköpts, är fosforsyreförsörjningen sämre.

Kartan i bild 6 återger fosforsyreförsörjningen i en by, där varje gårds ägor äro starkt splittrade. Bönder med $4-5$ ha åker ha denna spridd på åtminstone 40-50 skiften, som ligga strödda över hela byområdet. De enskilda bönderna gödsla olika starkt, varigenom den stora skillnaden i fosfatförsörjningen mellan närliggande åkertegar förklaras. I allmänhet är det så, att de bättre skolade bönderna också ha bättre gödslade åkrar. Det är påfallande att åkrarna i närheten av byn i många fall äro fosfatrikast.

I och med bestämningen av fosforsyra-, kali- och kalkbehovet har vi naturligtvis endast klarat upp några av tillväxtfaktorerna, även om det gäller de tre viktigaste. Därtill vore det framför allt önskvärt att kunna bestämma jordens kvävebehov; det har dock redan omtalats att detta för närvarande icke är möjligt, emedan jordens nitrathalt växlar utomordentligt mycket. Försök pågår emellertid för att även för denna bestämning utveckla en användbar metod. Fackgruppen för jordanalys i VDLUFA försöker nu få fram snabbmetoder för bestämning av spårelement, framförallt bor, för bestämning av humushalt och humustillstånd, för bestämning av basmättningskapacitet, alltså det så kallade T-värdet, liksom också för jordens fysikaliska egenskaper. Med hjälp av dessa faktorer kan det sedan bli möjligt att göra en fullständigare jordbedömning.

Med de beskrivna metoderna har i Tyskland hittills utförts över 10 milj. jordanalyser. Utan att ingå på några detaljer skulle jag gärna som avslutning vilja gå in på några anmärkningsvärda resultat, som erhållits vid ifrågavarande undersökningar.

En fosfatkarta (bild 7) över Tyskland och angränsande områden har visat att fosfatförsörjningen i Tyskland är förhållandevis mycket dålig. Såtillvida finns emellertid anmärkningsvärda skillnader, att försörjningen i de väștra områderna är bättre än i de mellersta delarna och att den i de mellersta delarna återigen är bättre än i Östtyskland. Huvudorsaken därtill består i att produktionen av thomasfosfat, det i Tyskland förut vanligaste fosfatgödselmedlet, sker i Västtyskland och att man i Östtyskland på grund av jordbrukets extensiva karaktär, och framför allt på grund av längre transportvägar, har använt mindre mängder fosfatgödselmedel. En ytterligare orsak är att man i Västtyskland infört mycket kraftfoder från utlandet och även livsmedel och fodermedel från Östtyskland utan att tillföra mer fosfatgödsel som utjämning till områderna i öster. Man kan påvisa nära samband mellan jordbrukets intensitet och jordens fosfathalt, liksom det överhuvudtaget finns ett nära samband mellan "Thünenscher Kreislehre» och jordens fosfattillstånd (11).

Liknande betraktelser kunna naturligtvis även anställas beträffande hela Europa eller hela världen. Vid systematiska fosfatundersökningar inom en så vid 


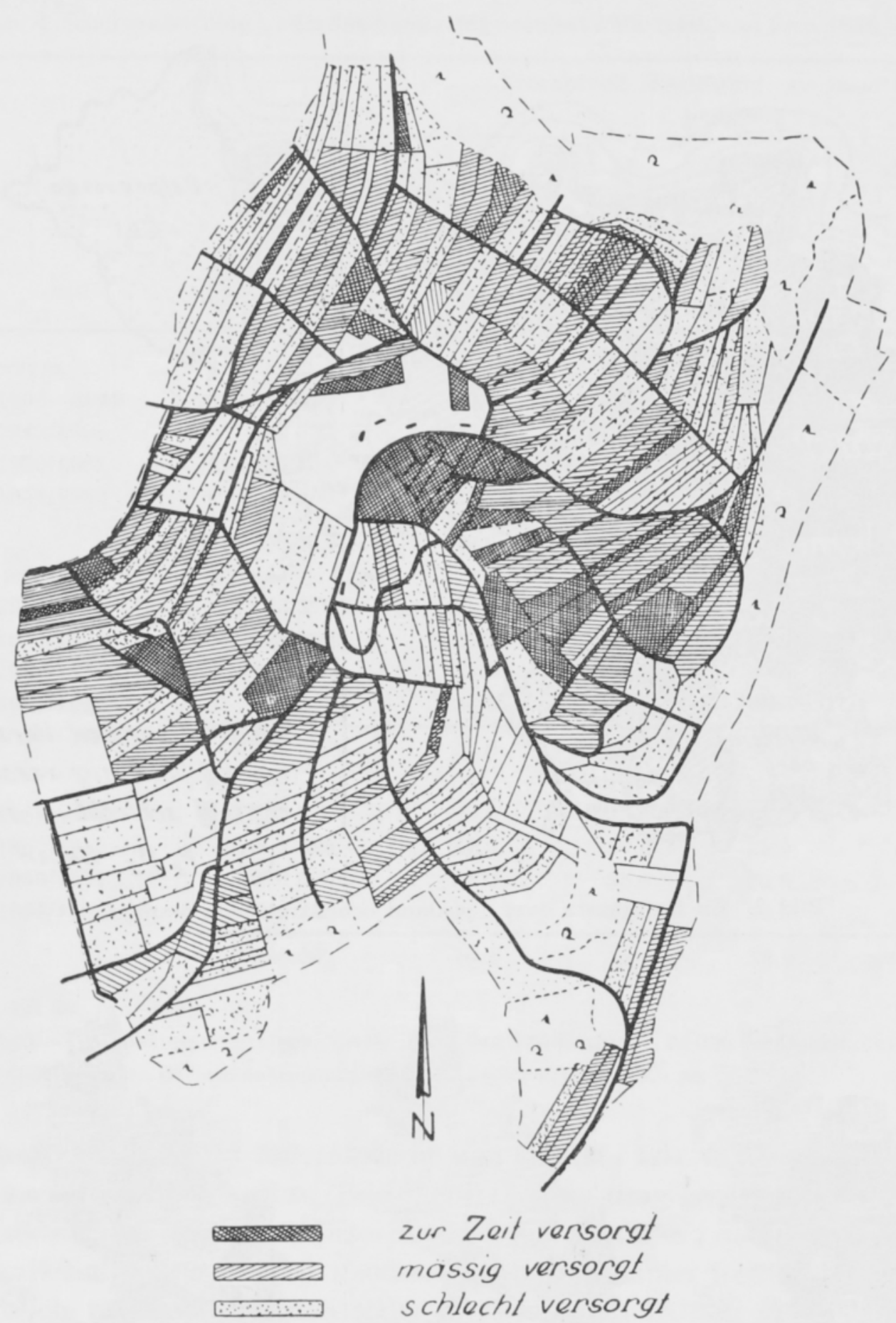

Bild 6. Fosforsyreförsörjning i en by, där varje gârds ägor äro starkt splittrade.

ram får man dock vänta sig många undantag. Man kommer att finna att gamla kulturcentra alltid äro särskilt fosfatrika, även om de numera icke äro intensivt odlade. Fosforsyran borttvättas knappast alls ur jorden, varför en engång åstadkommen fosfatanrikning ibland kan bliva bestående under århundraden. Därför kan ju fosfatanalysen också användas för att uppsöka arkeologiska fyndplatser, något som O. Arrhenius har fäst uppmärksamheten på. I Tyskland har senare Lorch gjort sådana undersökningar enligt en av honom förbättrad metod, varöver han har publicerat åtskilliga arbeten. 


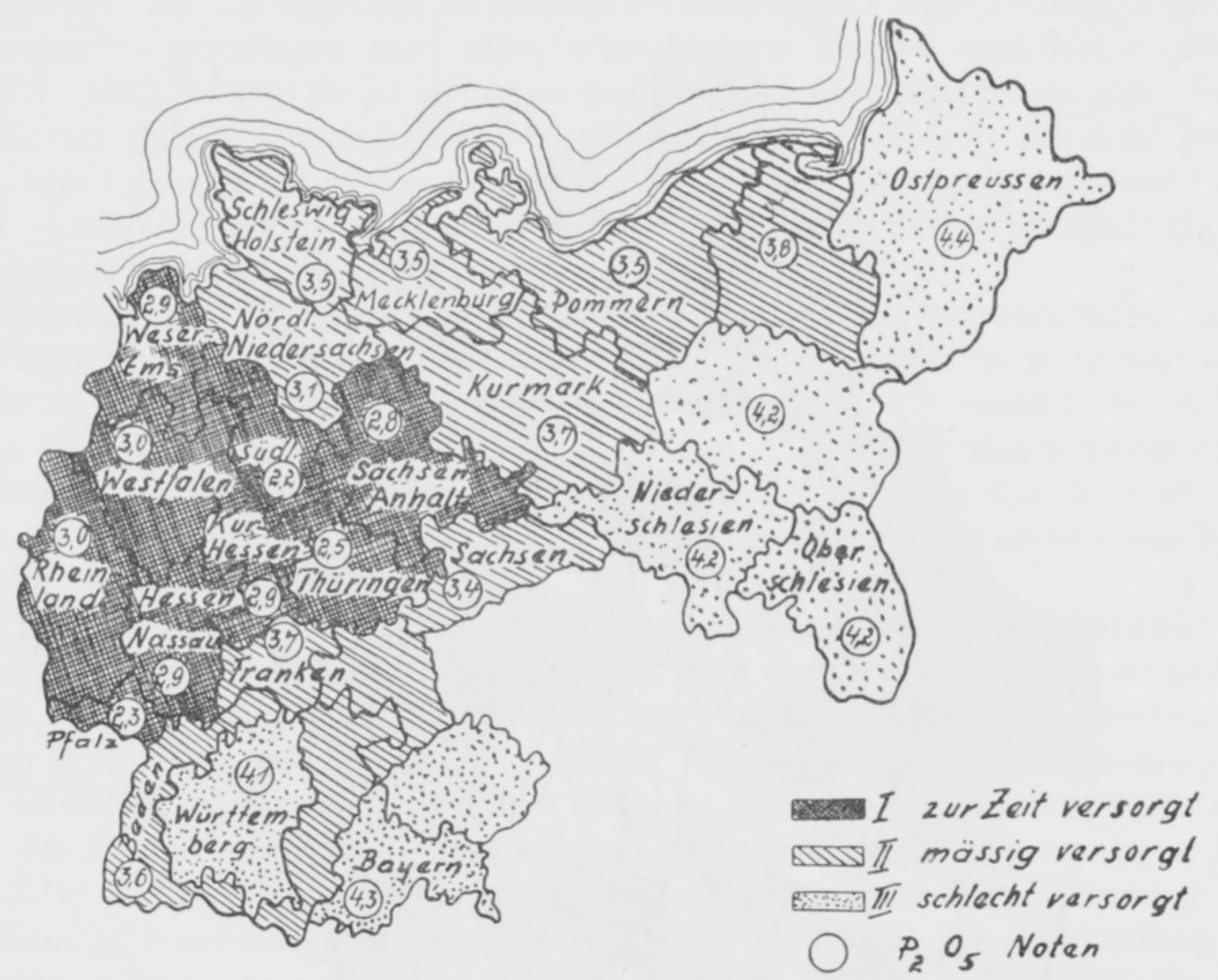

Bild 7. En fosfatkarta över Tyskland och närstãende omrâden.

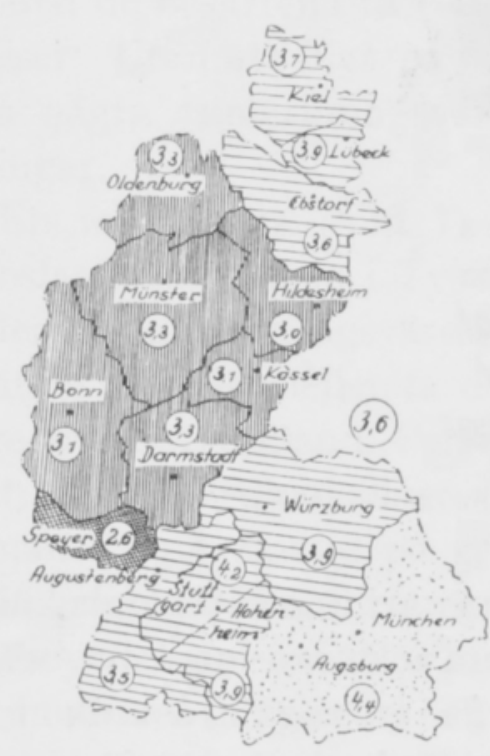

PHOSPHORSAUURE

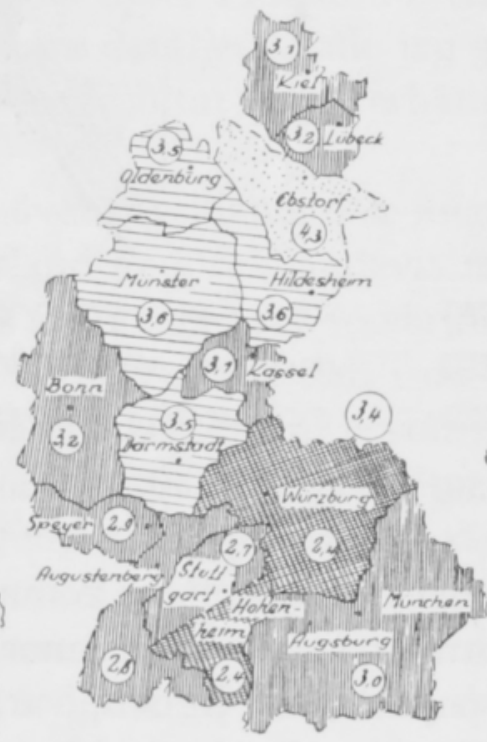

KALi

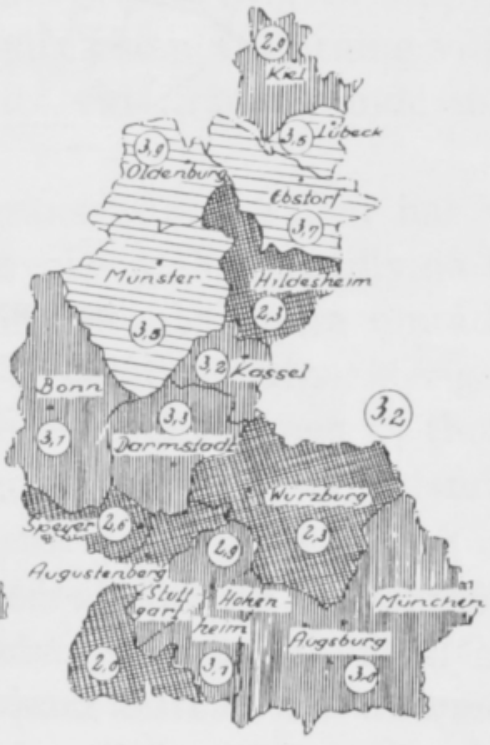

KALK

$\Longrightarrow$

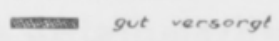

schieche rersorgt

Bild 8. Fosfat-, kali- och kalkkartor över Västtyskland. 
Tab. 4. Sammanfattning av jordundersökningsresultat i Västtyskland åren $1936-52^{1}$

\begin{tabular}{|c|c|c|c|c|c|c|}
\hline & \multirow{3}{*}{$\begin{array}{l}\text { Antal } \\
\text { prov }\end{array}$} & \multicolumn{4}{|c|}{$\begin{array}{l}\text { Procentuell fördelning av resultaten } \\
\text { i gruppen }\end{array}$} \\
\hline & & & $\begin{array}{c}\text { I } \\
\text { (för } \\
\text { närv. } \\
\text { försörjd) }\end{array}$ & $\begin{array}{c}\text { II } \\
\text { (måttl. } \\
\text { för- } \\
\text { sörjd) }\end{array}$ & $\begin{array}{c}\text { III } \\
\text { (dåligt } \\
\text { för- } \\
\text { sörjd) }\end{array}$ & $\begin{array}{l}\text { "Närings- } \\
\text { betyg" }\end{array}$ \\
\hline \multicolumn{2}{|r|}{. } & & $\%$ & $\%$ & $\%$ & \\
\hline \multicolumn{7}{|c|}{ Fosforsyra } \\
\hline & $1936-1949$ & 3302390 & 20.5 & 30.3 & 49.2 & 3.6 \\
\hline & $1949 / 1950$ & 702026 & 20.9 & 33.8 & 45.3 & 3.5 \\
\hline & $1950 / 1951$ & 880151 & 20.0 & 35.0 & 45.0 & 3.5 \\
\hline & $1951 / 1952$ & 949050 & 21.6 & 33.3 & 45.1 & 3.5 \\
\hline & & 5833617 & 20.9 & 32.2 & 46.9 & 3.6 \\
\hline \multicolumn{7}{|l|}{ Kali } \\
\hline & $1936 / 1949$ & 1583370 & 21.4 & 37.2 & 41.4 & 3.4 \\
\hline & $1949 / 1950$ & 702026 & 26.8 & 37.8 & 35.4 & 3.2 \\
\hline & $1950 / 1951$ & 880151 & 25.0 & 38.0 & 37.0 & 3.3 \\
\hline & $1951 / 1952^{2}$ & 949050 & 24.7 & 40.9 & 34.4 & 3.2 \\
\hline & & 4114.597 & 24.0 & 38.9 & 37.1 & 3.3 \\
\hline \multicolumn{7}{|l|}{ Kalk } \\
\hline & $1936-1949$ & 3351326 & 29.8 & 32.2 & 38.0 & 3.2 \\
\hline & $1949 / 1950$ & 608528 & 37.0 & 35.0 & 28.0 & 2.8 \\
\hline & $1950 / 1951$ & 670596 & 31.0 & 35.0 & 34.0 & 3.1 \\
\hline & $1951 / 1952^{2}$ & 949.753 & 32.1 & 31.3 & 36.6 & 3.1 \\
\hline & & 5580203 & 30.3 & 32.9 & 36.8 & 3.1 \\
\hline
\end{tabular}

Jordundersökningar $i$ Västtyskland är framställda i tab. 4. Resultaten har landsdelsvis sammanställts på kartan (Bild8) (13). I stora drag kan man se att jordarna i områdets södra delar äro sämre försörjda med fosforsyra än i mellersta delen, medan kali och kalkförsörjning är bäst i söder. Vad näringsämnet fosforsyra beträffar går detta parallelt med gödslingen; i söder används bara hälften så mycket handelsgödsel som i mellersta delen. För kali- och kalkkartan är förhållandena icke så enkla, emedan här jordens naturliga kali- och kalkhalt spela en större roll.

De på kartan angivna talen betyder »näringsbetyg» som erhållas på följande sätt:

Procentdelen i klass I multipliceras med 1, i klass II med 3 och i klass III med 5. Dessa tre produkters summa divideras med 100.

Man får på detta sätt tal mellan 1 och 5 , varvid 1 betyder att $100 \%$ av jordarna tillhöra i den väl försörjda klassen och 5 att $100 \%$ tillhöra i den dåligt försörjda klassen och 3 till exempel motsvarar 100 \% i den måttligt försörjda klassen.

Vi erhålla på detta sätt direkt näringsbetyg, som kunna jämföras med skolbetyg. Det har visats sig mycket tacksamt att arbeta med sådana betyg. Detta enda 
Tab. 5. Näringsförsörjningen i badensiska åker- och ängsjordar (undersökningar fram till 1951).

\begin{tabular}{|c|c|c|c|c|c|c|c|c|c|c|c|}
\hline & & \multirow{2}{*}{$\begin{array}{l}\text { Antal } \\
\text { jord- } \\
\text { prov }\end{array}$} & \multicolumn{3}{|c|}{ Fosforsyra } & \multicolumn{3}{|c|}{ Kali } & \multicolumn{3}{|c|}{ Kalk } \\
\hline & & & $\begin{array}{c}\text { för } \\
\text { närv. } \\
\text { för- } \\
\text { sörjd } \\
\text { \% }\end{array}$ & $\begin{array}{l}\text { måt- } \\
\text { tligt } \\
\text { för- } \\
\text { sörjd } \\
\%\end{array}$ & $\begin{array}{l}\text { dåligt } \\
\text { för- } \\
\text { sörjd } \\
\text { \% }\end{array}$ & $\begin{array}{c}\text { för- } \\
\text { närv. } \\
\text { för- } \\
\text { sörjd } \\
\text { \% }\end{array}$ & $\begin{array}{c}\text { mått- } \\
\text { ligt } \\
\text { för- } \\
\text { sörjd } \\
\%\end{array}$ & $\begin{array}{l}\text { dåligt } \\
\text { för- } \\
\text { sörjd } \\
\text { \% }\end{array}$ & $\begin{array}{c}\text { för } \\
\text { närv. } \\
\text { för- } \\
\text { sörjd } \\
\%\end{array}$ & $\begin{array}{l}\text { mått- } \\
\text { ligt } \\
\text { för- } \\
\text { sörjd } \\
\%\end{array}$ & $\begin{array}{l}\text { dåligt } \\
\text { för- } \\
\text { sörjd } \\
\%\end{array}$ \\
\hline Åker & 211 & 867 & 29.3 & 30.7 & 40.0 & 58.4 & 30.9 & 10.7 & 70.5 & 13.0 & 16.5 \\
\hline Äng & 73 & 157 & 12.6 & 20.5 & 66.9 & 32.0 & 32.1 & 35.9 & 55.9 & 9.1 & 35.0 \\
\hline Total & 285 & 024 & 25.0 & 28.1 & 46.9 & 51.8 & 31.2 & 17.0 & 66.8 & 12.0 & 21.2 \\
\hline
\end{tabular}

tal säger oss genast hur näringsförhållandena gestalta sig på olika gods, i olika byar, och i olika landsdelar. Betygen äro särskilt värdefulla vid löpande kontroll av näringsförsörjningen, ty det visar omedelbart om förändringar har inträffat.

Den ringa användningen av handelsgödsel $i$ Sydtyskland förorsakas av att gårdarna $\mathrm{i}$ jordbruken inom detta område äro mindre, och framförallt av den långt drivna ägosplittringen. Jordundersökningar i Sydtyskland, särskilt i mitt eget område i Baden, visar nämligen att det är stor skillnad mellan små- och storjordbrukens försörjning med växtnäringsämnen. Medan odlingsmarkerna hos storjordbruken även hos oss i allmänhet ha en tillfredsställande näringstillstånd är detta hos de små jordbruken i synnerhet vid stor ägosplittring utomordentligt dålig. A andra sidan har jordundersökningarna redan åstadkommit att dessa små jordbruk börjat använda mer gödselmedel.

Särskilt dålig är betesvallarnas försörjning med näringsämnen. Detta beror en på i att under kriget ingen tilldelning av gödselmedel gavs för betesvall, en annan orask är den att bönderna i allmänhet försumma betesvallarna redan på grund därav, att de för det mesta ligga så avlägset.

Av tabell 5 framgår att ängs- (betesvalls) jordarna äro betydligt sämre försörjda med fosforsyra, kali och kalk än åkerjordarna. Detta resultat hänför sig icke endast till Baden utan visar sig i alla Västtysklands landsdelar.

Ängsjordarnas dåliga näringsförsörjning medför icke endast en låg höskörd utan framförallt också dålig hökvalitet. De nära 500 höanalyser som vi förra året genomförde i norra Baden visade en särskilt låg baljväxt- och gräshalt i höet. Detta innebär utom låg äggvitehalt även låg mineralämneshalt, framförallt låg fosforsyrehalt. I medeltal för alla prov belöpte sig fosforsyrehalten till endast $0.38 \% \mathrm{P}_{2} \mathrm{O}_{5}$, på de prov, som hade vuxit på jordar med dålig fosfatförsörjning till och med endast $0.34 \%$, medan som bekant en normal fosforsyrehalt i höet utgör ungefär $0.60 \%$.

En väsentlig förbättring av läget hos våra små jordbruk kommer att inträffa först när man genom omskiftning åstadkommit en sammanslagning av småtegarna. Vi samarbeta därför nära med lantmätarna, och ha också erhållit anmärkningsvärda resultat med hjälp av våra jordundersökningar, som vid lantmätarnas propaganda hos bönderna för omskiftning gjort god nytta. Så har vi till exempel funnit, genom särskilt nogranna provtagningar på smala åkertegar, att näringsinne- 
Tab. 6. Ägosplittring, ojämn näringshalt och skörderesultat på smala åkertegar. Kantdelar och mellandelar på smala åkertegar har undersökts var för sig på innehåll av näringsämnen och även skördats var för sig (siffrorna äro relativtal).

\begin{tabular}{lcccc}
\hline & \multicolumn{2}{c}{ Näringsämne } & Skörd & Kärna eller \\
\cline { 2 - 5 } & $\mathrm{P}_{2} \mathrm{O}_{5}$ & $\mathrm{~K}_{2} \mathrm{O}$ & Halm \\
\hline $\begin{array}{l}\text { Mitten av tegen } \\
\text { Genomsnitt av tegsidarna för: }\end{array}$ & 100 & 100 & 100 & 100 \\
Havre & 60 & 43 & 72.5 & 67 \\
Råg & 55.5 & 85 & 84 & 78 \\
Potatis & 73 & 56 & 73 & - \\
Foderbetor & 87 & 72 & 53 & - \\
\hline
\end{tabular}

hållet i tegens mitt alltid är betydligt högre än i dess kant. Därför är också skördens storlek nära kanten lägre än i tegens mitt. Exempel härpå ger tabell 6 (13). Exemplen visar att näringsinnehållet i samtliga fall är mindre i tegarnas utkant och att skörden är motsvarande lägre. Tegkanternas lägre näringsinnehåll förorsakas av att bönderna alltid äro mycket försiktiga med gödslingen. De gödslar framför allt i mitten, naturligtvis för att undvika att någon gödsel kommer på grannens mark.

Den eftersträvade utökade användningen av handelsgödsel är icke skadlig för jorden om den görs riktigt utan tvärtom. Genom den kommer jordens bördighet endast att stiga. Man han nämligen påvisa ett kretslopp för jordens bördighet, i så måtto att genom utökad användning av handelsgödsel foderskördarna liksom halmskördarna stiga, varigenom större djurbesättning kan hållas, stallgödselmängden stiger, rotmassan ökas, jordens humushalt ökas och slutligen jordens bördighet i sin tur stiger (15).

Med mitt anförande har jag velat visa hur jordundersökningarna i Tyskland för närvarande utföras och vilken betydelse de har för vårt jordbruk. Jordundersökningarnas huvudändamål är att ge jordbrukarna den nödvändiga förutsättningen för ekonomisk användning av tillgängliga gödselmedel. Slutmålet för alla jordundersökningar blir en löpande näringskontroll med regelbundna tidsintervaller av $3-5$ år, för att kontrollera gödslingsåtgärdernas ändamålsenlighet, att vid behov söka färbättra jorden, att bibehålla den frisk och därmed säkra höga och jämna skördar.

\section{LITTERATURFÖRTECKNING}

(1) Brouwer, W. 1949. Steigerung der Erträge der Hülsenfrüchte durch Beregnung sowie Fragen der Bodenuntersuchung und Düngung. Ztschr. f. Acker- u. Pflanzenbau, 91, p. 319—346.

(2) Egnér, H. 1932. Metod att bestämma lättlöslig fosforsyra i åkerjord. Meddelande Nr. 425. från Centralanstalten för försöksväsendet på jordbruksområdet. Avdelningen för lantbrukskemie, 51, Stockholm. 
(3) Egnér, Köhler, G. und Nydahl, F. 1938. Die Laktatmethode zur Bestimmung leichtlöslicher Phosphorsäure in Ackerböden. Ann. der Landwirtschaftlichen Hochschule Schwedens, p. $253-296$.

(4) FRANCK, O. 1935. Undersökningar rörande den lättlösliga fosforsyran i våra odlingsmarker. Meddelande Nr. 456 från Centralanstalten för försöksväsendet på jordbruksområdet. Jordbruksavdelningen, 91, Stockholm.

(5) GEricke, S. 1948. Die mineralischen Nährstoffe als Grundlage einer Leistungssteigerung in der deutschen Landwirtschaft. Ztschr. f. Pflanzenern., Düng. u. Bodenkunde, 41 (86) $64-76$.

(6) —- und v. Zezschwize, E. 1952. Phosphorsäuregehalt und Leistung des Bodens. Die Phosphorsäure, 12 .

(7) Oece Les engrais dans les programmes de relevement agricole. Oece chateau de la Paris.

(8) Rгенм, H. 1943. Untersuchungen über die zweckmässigste Art der Probenahme für chemische Bodenkontrolle. Bodenk. u. Pflanzenern., 29, p. 275-291.

(9) —— 1944. Versuche über die Reproduzierbarkeit der Bodenprobenahme. Ibid. 33, p. 235-249.

(10) - 1948. Sitzungsbericht der zweiten Tagung der \#Arbeitsgemeinschaft Bodenuntersuchungen der Landwirtschaftlichen Versuchsstationen des amerikanisch besetzten Gebietes* an der Bad. Staatl. Landwirtschaftl. Versuchs- und Forschungsanstalt Augustenberg am 31. 7. u. 1. 8. 1947 Ibid., 40, p. 135-172.

(11) - 1949. Bodenuntersuchung und Thünen'sche Kreislehre. (Besondere Anwendung der Phosphatanalyse). Ibid., 43, (88.), p. 133-143.

(12) —- 1949. Der Nährstoffzustand der Böden der Westzonen Deutschlands. Landwirtschaftliche Forschung, Darmstadt, 1, p. 141-147.

(13) $\rightarrow$ 1949. Bodenuntersuchung und Feldbereinigung. Ztschr. f. Pflanzenern., Düng. u. Bodenkunde, Lemmermannfestschrift, 47 (92.), p. $16-28$.

(14) Schachtschabel, P. 1941. Weitere Untersuchungen über die Bestimmung des Kalkbedarfs. Ivid. $25,0,37-57$.

(15) Schmit, L. 1949. Kreislauf der Bodenfruchtbarkeit. Landw. Lehrhefte, Heft 1_24. Just v.Liebig Verlag, Darmstadt.

Z U S A M E N F A S U N G :

BODENUNTERSUCHUNGEN IN DEUTSCHLAND UND IHRE BEEDUTUNG FUR DIE PRAKTISCHE LANDWIRTSCHAFT

Vortrag gehalten von Dr. H. Riенм, Augustenberg, Baden-Württenberg, in Helsinki am 14. 9.1952.

Die Bodenuntersuchung kann mit dazu beitragen, die in vielen Ländern wünschenswerte Erhöhung der Düngemittelanwendung zu beschleunigen.

Nach Angabe der zweckmässigsten Art der Probenahme für die chemische Bodenuntersuchung wird auf die in Deutschland gebräuchlichen Methoden zur Bestimmung des Kalkbedarfs nach ScHAcHTSCHABEL und zur Bestimmung des Phosphorsäure- und Kalibedarfs nach EGnÉR-RIEHM eingegangen. Es werden vor allem auch die kolorimetrische Molybdänblau-Methode und die flammenphotometrischen Methoden geschildert. Die richtige Auswertung der Ergebnisse ist für den Landwirt das Entscheidende.

Die etwa 10 Millionen Bodenuntersuchungen in Deutschland ergaben, dass sowohl der Kalk- als auch der Phosphorsäure- und Kalizustand der Böden zu wünschen übrig lässt. Besonders gilt dies für die Böden der kleineren Landwirte und bei denen vor allem für das Grünland. Die Bodenuntersuchung kann auch bei der Massnahme der Ackerzusammenlegung durch Feldbereinigung wertvolle Hilfe leisten.

Ziel der Bodenuntersuchung ist eine laufende Nährstoffkontrolle in regelmässigen Abständen von 3-5 Jahren, um die Zweckmässigkeit der Düngungsmassnahmen zu kontrollieren, den Boden notfalls zu heilen, ihn gesund zu erhalten und damit hohe und sichere Erträge zu gewährleisten. 